\section{North Atlantic hotspot-ridge interaction near Jan Mayen Island}

\section{L.J. Elkins ${ }^{1,2 *}$, C. Hamelin ${ }^{3 *}$, J. Blichert-Toft ${ }^{4}$} S.R. Scott' ${ }^{5}$, K.W.W. Sims ${ }^{5}$, I.A. Yeo ${ }^{6}$ C.W. Devey ${ }^{6}$, R.B. Pedersen ${ }^{3}$

\section{Abstract}

At slow to ultraslow spreading rates along mid-ocean ridges, thicker lithosphere typically impedes magma generation and tectonic extension can play a more significant role in crustal production (Dick et al., 2003). The source of anomalously high magma supply thus remains unclear along ridges with ultraslow-spreading rates adjacent to Jan Mayen Island in the North Atlantic (Neumann and Schilling, 1984; Mertz et al., 1991; Haase et al., 1996; Schilling et al., 1999; Trønnes et al., 1999; Haase et al., 2003; Mertz et al., 2004; Blichert-Toft et al., 2005; Debaille et al., 2009). Here we show that Jan Mayen volcanism is likely the surface expression of a small mantle plume, which exerts significant influence on nearby mid-ocean ridge tectonics and volcanism. Progressive dilution of Jan Mayen geochemical signatures with distance from the hotspot is observed in lava samples from the immediately adjacent Mohns Ridge, and morpholo ine Ridge and the neterogeneous, eclogite-bearing mantle source. These morphological and geochicalinfluences thus the local expression of tectonic boundaries.

Received 17 August 2015 | Accepted 21 December 2015 | Published 22 January 2016

Department of Geology, Bryn Mawr College, 101 North Merion Avenue, Bryn Mawr, Pennsylvania 19010, USA

Department of Earth and Atmospheric Sciences, University of Nebraska Lincoln, Lincoln, NE 68588, USA

3 Center for Geobiology, University of Bergen, Allegaten 41 5007, Bergen, Norway

Laboratoire de Géologie de Lyon, Ecole Normale Superieure de Lyon, 46 Allée d'Italie, 69007 Lyon France

5 Department of Geology and Geophysics, University of Wyoming, Laramie, Wyoming 82071, USA

6 GEOMAR, Helmholtz Center for Ocean Research Kiel, Wischhofstraße 1-3 24148, Kiel, Germany

The normal accretion process along divergent plate boundaries can be notably altered in hotspot-ridge interaction settings, where elevated mantle temperature anomalies enhance mantle melting, generating unusually thick oceanic crust (e.g., Schilling et al., 1985; Schilling, 1991; Gale et al., 2013, 2014). Jan Mayen and its immediate environs in the North Atlantic (Fig. 1) include an intraplate, volcanically-active island or hotspot (Jan Mayen Island), positioned at the northern terminus of a small, rifted microcontinent (Jan Mayen Ridge; Johnson and Heezen, 1967; Kodaira et al., 1997; Gaina et al., 2009) and adjacent to two second-order ultraslow-spreading (Dick et al., 2003) ridge segments, the Northern Kolbeinsey Ridge (NKR) and Southern Mohns Ridge (SMR), and the Jan Mayen Fracture Zone, a major fracture zone with $\sim 200 \mathrm{~km}$ of transform offset. Although different in key ways, broad geochemical similarities between Jan Mayen Island and Icelandic lavas have suggested the influence of a mantle plume (either a unique Jan Mayen plume or emplaced Icelandic material) on mantle melting beneath Jan Mayen Island (Schilling et al., 1999; Trønnes et al., 1999; Debaille et al., 2009). The absence of a clear hotspot track has led to conflicting, alternate interpretations for Jan Mayen's high magma production rate and enriched chemistry (Imsland, 1986; Maaløe et al., 1986; Thy et al., 1991): cold edge effects near the fracture zone (Mertz et al., 1991; Haase et al., 1996), variably melting source heterogeneities (Mertz et al., 1991; Haase et al., 2003; Mertz et al., 2004), upwelling along a mantle chemical discontinuity (Blichert-Toft et al., 2005), or a locally wet mantle (Haase et al., 2003; Mertz et al., 2004). Jan Mayen thus presents a useful case study for 1) exploring the mechanisms by which hotspot volcanism can influence ultraslow-spreading ridge morphology, behaviour, and volcanism, 2) determining the relationships between hotspot volcanism and ambient variations in mantle geochemistry, and 3) exploring the disputed origins of local volcanic activity.

For this study, we present comprehensive geochemical analyses (major and trace element concentrations and ${ }^{87} \mathrm{Sr} /{ }^{86} \mathrm{Sr},{ }^{143} \mathrm{Nd} /{ }^{144} \mathrm{Nd},{ }^{176} \mathrm{Hf} /{ }^{177} \mathrm{Hf},{ }^{206} \mathrm{~Pb} /{ }^{204} \mathrm{~Pb}$, ${ }^{207} \mathrm{~Pb} /{ }^{204} \mathrm{~Pb}$, and ${ }^{208} \mathrm{~Pb} /{ }^{204} \mathrm{~Pb}$ compositions) for a suite of submarine volcanic rocks from the NKR, the SMR, and Jan Mayen Island (Tables 1, S-1, S-2, S-3). These geochemical results are interpreted in the context of an enhanced geologic perspective, thanks to new high-resolution bathymetry of the volcanic and tectonic submarine morphology (Fig. 1). All submarine samples were retrieved during recent research cruises in combination with new multibeam bathymetry (Pedersen et al., 2010; Devey, 2012). Three additional, subaerial alkali basalts from Jan Mayen Island are included for literature comparison (Maaløe et al., 1986).

In agreement with previous work (Trønnes et al., 1999; Debaille et al., 2009), Jan Mayen Island lavas are "enriched" with relatively high ${ }^{87} \mathrm{Sr} /{ }^{86} \mathrm{Sr},{ }^{206} \mathrm{~Pb} /{ }^{204} \mathrm{~Pb}$ ${ }^{207} \mathrm{~Pb} /{ }^{204} \mathrm{~Pb}$, and ${ }^{208} \mathrm{~Pb} /{ }^{204} \mathrm{~Pb}$ and low $\varepsilon_{\mathrm{Hf}}$ and $\varepsilon_{\mathrm{Nd}}\left(e . g .{ }^{87} \mathrm{Sr} /{ }^{86} \mathrm{Sr}=0.703368-\right.$ 0.703490 ) (Table 1), and with trace element abundances resembling other ocean island basalts (Table S-2, Fig. S-1). While similar, Jan Mayen area lavas exhibit a 


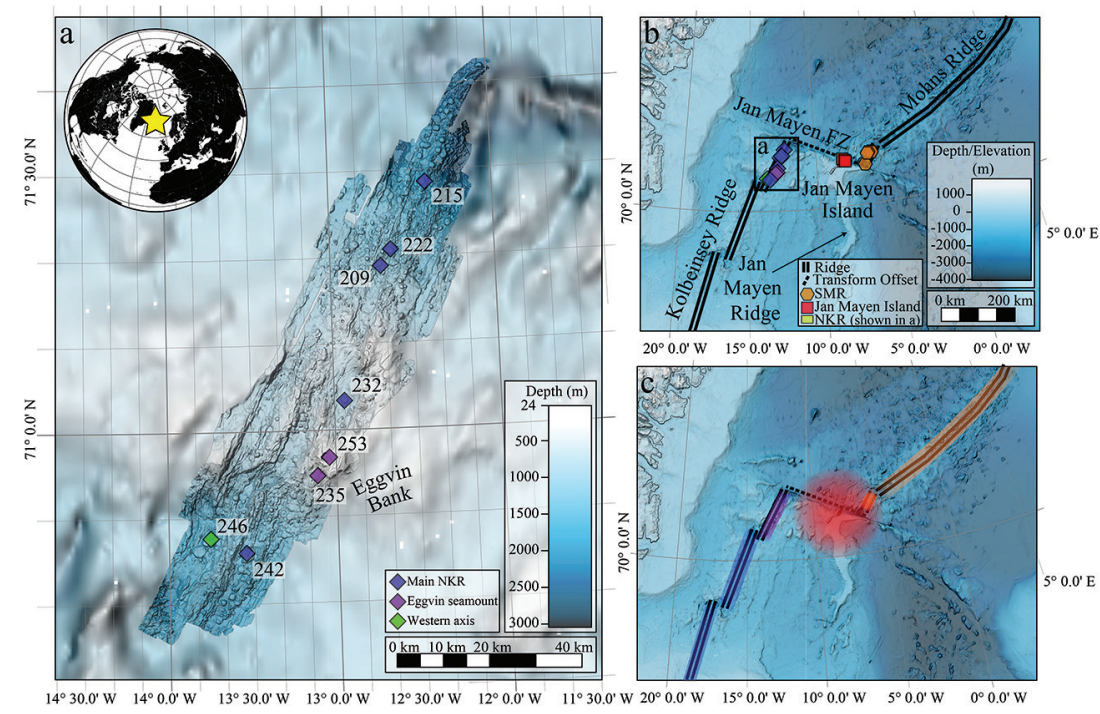

Figure 1 (a) Multibeam bathymetric map of the NKR, showing the Eggvin Bank and numbered dredge locations for samples analysed in this study. (b) Regional bathymetric map showing distribution of labelled seafloor features and Jan Mayen Island, with sample locations for this study from Jan Mayen Island (red), NKR (colours as in panel a), and SMR (orange). (c) Map with highlighted areas showing the proposed zones of underlying mantle melt generation and migration (blue: Kolbeinsey-type; purple: Eggvin-type; orange: Mohns-type; and red circle Jan Mayen-type mantle).

distinct geochemical composition from Icelandic lavas (e.g., higher ${ }^{87} \mathrm{Sr} /{ }^{86} \mathrm{Sr}$ and $\mathrm{Pb}$ isotope ratios, lower ${ }^{143} \mathrm{Nd} /{ }^{144} \mathrm{Nd}$ and ${ }^{176} \mathrm{Hf} /{ }^{177} \mathrm{Hf}$, normal MORB ${ }^{3} \mathrm{He} /{ }^{4} \mathrm{He}$, and distinct ${ }^{187} \mathrm{Os} /{ }^{188} \mathrm{Os}$ on Jan Mayen Island; Schilling et al., 1999; Hanan et al., 2000; Blichert-Toft et al., 2005; Debaille et al., 2009), suggesting an enriched source discrete from the Icelandic hotspot source, possibly entraining subcontinental lithospheric mantle (SCLM) (Debaille et al., 2009). The submarine samples from Jan Mayen Island appear relatively evolved compared to the most magnesian subaerial samples of this study $(\mathrm{MgO}=5.1-6.45$ vs. $10.6-11.1$ wt. \%; Table S-3), but as previously observed, there are no systematic trace element or isotopic variations correlating with differentiation, arguing against detectable crustal assimilation (Trønnes et al., 1999) (Tables 1, S-2, S-3).

The Mohns Ridge is an ultraslow-spreading ridge (17 $\mathrm{mm} \mathrm{yr}^{-1}$ full-spreading rate; Mosar et al., 2002; Dick et al., 2003) north of Jan Mayen Island with relatively thin crust ( $4 \mathrm{~km}$; Klingelhofer et al., 2000; Okino et al., 2002; Ljones et al., 2004; Kandilarov et al., 2008) and mainly characterised by highly oblique spreading expressed as a series of en echelon rift basins (Géli et al., 2012). In contrast, its southern segment (the SMR) has an orthogonal spreading direction and irregular off-axis crustal morphology, with a shallower ridge axis and thicker crust ( 10 km; Kandilarov et al., 2012) (Fig. 1). Recent mapping indicates the presence of large, partly eroded volcanic structures, often bisected by faulting (Pedersen et al., 2010). We interpret these structural and morphological characteristics as indicative of magma supply considerably higher than along the rest of the Mohns Ridge, possibly reflecting the influence of a nearby mantle plume associated with enhanced melt production.

Table 1 Radiogenic isotope compositions measured by ICP-MS*.

\begin{tabular}{|c|c|c|c|c|c|c|c|}
\hline Sample & Location $^{* *}$ & ${ }^{87} \mathrm{Sr}{ }^{186} \mathrm{Sr}$ & ${ }^{176} \mathrm{Hf} /{ }^{177} \mathrm{Hf}$ & ${ }^{143} \mathrm{Nd} /{ }^{144} \mathrm{Nd}$ & ${ }^{206} \mathrm{~Pb} /{ }^{204} \mathrm{~Pb}$ & ${ }^{207} \mathrm{~Pb} /{ }^{204} \mathrm{~Pb}$ & ${ }^{208} \mathrm{~Pb} /{ }^{20}$ \\
\hline \multicolumn{8}{|c|}{ Submarine samples: } \\
\hline POS436 242DR-2ba & NKR & $0.703151(5)$ & $0.283175(5)$ & $0.513006(6)$ & 18.8926 & 15.5093 & 38.6157 \\
\hline POS436 246DR-2a & NKR & $0.702961(6)$ & $0.283255(4)$ & $0.513083(5)$ & 18.4553 & 15.4547 & 38.0857 \\
\hline POS436 235DR-1 $\mathrm{a}^{\mathrm{a}}$ & NKR & $0.703187(5)$ & $0.283177(4)$ & $0.513008(5)$ & 18.8756 & 15.5177 & 38.5990 \\
\hline POS436 253DR-E2a & NKR & $0.703195(7)$ & $0.283175(4)$ & $0.513015(5)$ & 18.8899 & 15.5211 & 38.6184 \\
\hline POS436 253DR-6a & NKR & $0.703203(7)$ & $0.283183(4)$ & $0.513019(5)$ & 18.8881 & 15.5185 & 38.6109 \\
\hline POS436 232DR-1 ${ }^{\text {a }}$ & NKR & $0.703047(7)$ & $0.283217(4)$ & $0.513044(5)$ & 18.7881 & 15.5004 & 38.4908 \\
\hline POS436 209DR-2a ${ }^{a}$ & NKR & $0.703034(6)$ & $0.283231(4)$ & $0.513051(6)$ & 18.7699 & 15.5003 & 38.4689 \\
\hline POS436 222DR-1 ${ }^{\mathrm{a}}$ & NKR & $0.703040(7)$ & $0.283217(4)$ & $0.513043(6)$ & 18.8150 & 15.5047 & 38.5277 \\
\hline POS436 215DR-1 a $^{\mathrm{a}}$ & NKR & $0.703047(7)$ & $0.283203(4)$ & $0.513036(4)$ & 18.8538 & 15.5114 & 38.5652 \\
\hline SM01-DR-24-14 & JM & $0.703368(8)$ & - & $0.512910(5)$ & 18.8331 & 15.5057 & 38.5979 \\
\hline SM01-DR-23-3b & $\mathrm{JM}$ & $0.703456(6)$ & $0.283088(7)$ & $0.512931(5)$ & 18.8494 & 15.5070 & 38.6082 \\
\hline SM01-DR-5-5 & JM & $0.70343(8)$ & $0.283090(4)$ & $0.512914(5)$ & 18.8149 & 15.5061 & 38.5865 \\
\hline SM01-DR-60-43 & $\mathrm{JM}$ & $0.703431(8)$ & $0.283083(4)$ & $0.512918(5)$ & 18.8095 & 15.5051 & 38.5795 \\
\hline SM01-DR-100-01b & SMR & $0.703395(8)$ & $0.283233(5)$ & $0.512978(5)$ & 18.7946 & 15.4979 & 38.5077 \\
\hline CGB-2011-D17-2a ${ }^{\mathrm{a}}$ & SMR & $0.703339(6)$ & $0.283265(4)$ & $0.512991(6)$ & 18.7206 & 15.4949 & 38.4695 \\
\hline SM01-DR70-1 & SMR & $0.703391(5)$ & $0.283236(4)$ & $0.512979(5)$ & 18.7409 & 15.4995 & 38.4923 \\
\hline SM01-DR67-4 & SMR & $0.703417(8)$ & $0.283196(4)$ & $0.512983(5)$ & 18.8285 & 15.5012 & 38.5407 \\
\hline SM01-DR-91-13 & SMR & - & $0.283314(5)$ & - & - & - & - \\
\hline \multicolumn{8}{|c|}{ Subaerial samples (samples from Maaløe et al., 1986): } \\
\hline JM-192 & JM & $0.703490(7)$ & $0.283083(4)$ & $0.512880(6)$ & 18.7648 & 15.5167 & 38.6121 \\
\hline $\mathrm{JM}-71^{\mathrm{a}}$ & JM & $0.703454(6)$ & $0.283068(4)$ & $0.512901(5)$ & 18.8186 & 15.5170 & 38.6310 \\
\hline JM- $84^{\mathrm{a}}$ & JM & $0.703453(7)$ & $0.283087(4)$ & $0.512903(6)$ & 18.8404 & 15.5090 & 38.6229 \\
\hline
\end{tabular}

* Values in parentheses indicate $2 \sigma$ uncertainty for the last digit expressed.

** NKR: Northern Kolbeinsey Ridge; JM: Jan Mayen Island; SMR: Southern Mohns Ridge.

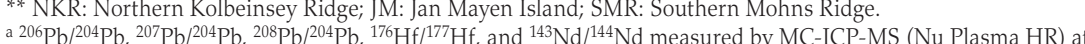
the Ecole Normale Supérieure de Lyon. Strontium isotopes were analysed at the University of Wyoming by MCICP-MS (ThermoFinnigan NeptunePlus). See Supplementary Information for further analytical details.

${ }^{b}$ Data measured at Bergen Geoanalytical Facility. ${ }^{87} \mathrm{Sr} /{ }^{86} \mathrm{Sr}$ measured by thermal ionisation mass spectrometry Data measured at Bergen Geoanalytical Facility. ${ }^{87} \mathrm{Sr} /{ }^{10} \mathrm{Sr}$ measured by thermal ionisation mass spectrometry MS (ThermoFinnigan Neptune). See Supplementary Information for further analytical details. 
Typical Mohns Ridge MORB are characterised by relatively high incompatible element contents and enriched radiogenic isotope values (Schilling et al., 1999; Elkins et al., 2014), but with relatively high ${ }^{208} \mathrm{~Pb} /{ }^{204} \mathrm{~Pb}$ and ${ }^{207} \mathrm{~Pb} /{ }^{204} \mathrm{~Pb}$ for a given ${ }^{206} \mathrm{~Pb} / 204 \mathrm{~Pb}$, akin to the so-called DUPAL anomaly observed in the southern oceans (Blichert-Toft et al., 2005). The lavas are further characterised by unusually high $\varepsilon_{\mathrm{Hf}}$ for a given $\varepsilon_{\mathrm{Nd}}$ (Blichert-Toft et al., 2005), best explained by ancient garnet in the mantle source, perhaps hosted by SCLM. Such a source could have originated as delaminated Greenland continental lithosphere during rifting of the relatively young Greenland basin. All SMR basaltic glasses analysed here are tholeiitic with geochemistry intermediate between typical Mohns Ridge MORB and lavas from Jan Mayen Island, readily explained as products of straightforward binary mixing between Mohns Ridge-type and Jan Mayen Island-type endmember magmas (Figs. 2, 3, S-1, S-2, Table 1).

Unlike the Mohns Ridge, the Kolbeinsey Ridge is overall characterised by orthogonal spreading at ultraslow rates (18 $\mathrm{mm} \mathrm{yr}^{-1}$; Mosar et al., 2002; Dick et al., 2003) and relatively thick ocean crust (7-10 km; Kodaira et al., 1997). The NKR segment has a shallower ridge axis and therefore thicker crust than the neighbouring Middle Kolbeinsey Ridge (MKR). While ultraslow ridges are typically characterised by thin crust, tectonic spreading, and peridotite exposure, those features are not observed in the Jan Mayen region despite ultraslow full-spreading rates of $17-18 \mathrm{~mm} \mathrm{yr}^{-1}$ (Mosar et al., 2002). Recent bathymetric mapping reveals that the Eggvin Bank in the centre of the NKR, in addition to being anomalously shallow, hosts fresh volcanic deposits indicative of high magma supply (e.g., sheet flows vs. monogenetic cones, a nearly subaerial volcanic edifice constructed atop the eastern axial flank wall, and fresh popping rocks) compared to the ends of the segment (Fig. 1). The large seamount lacks fresh fault scarps, suggesting elevated volcanic activity to maintain its height and cover active axial faulting. Regional bathymetry (Smith and Sandwell, 1997) demonstrates the presence off-axis of shallow seafloor and highly segmented slopes persisting up to $30 \mathrm{~km}(\sim 3 \mathrm{Ma})$ off-axis, further supporting a long-lived source of active volcanism. Bathymetry further reveals two parallel axial valleys to the south that both host fresh basalt (Fig. 1). This doubling of ridge axes suggests the segment is immature and can be explained by either active relocation of the segment towards the main, more easterly neovolcanic zone, or by simultaneously active, paired axial valleys as observed in Iceland. Either scenario suggests that NKR axial position is influenced by a long-lived source of enhanced magma supply.

Kolbeinsey Ridge basalts overall have notable depletions in incompatible trace elements and long-lived radiogenic isotope signatures, with high $\left.{ }^{230} \mathrm{Th} /{ }^{238} \mathrm{U}\right)$ activity ratios, together suggesting high degrees of melting of a depleted garnet peridotite source (Elkins et al., 2014). The abrupt change in purported mantle composition across the Jan Mayen Fracture Zone has been interpreted to indicate a sharp chemical discontinuity, perhaps reflecting a major mantle flow boundary (Haase et al., 1996) (Fig. 3). Former work identified more enriched isotopic and trace element signatures on the Eggvin Bank and NKR than the MKR, generally attributed to the influence of the Jan Mayen hotspot (Schilling et al., 1999;

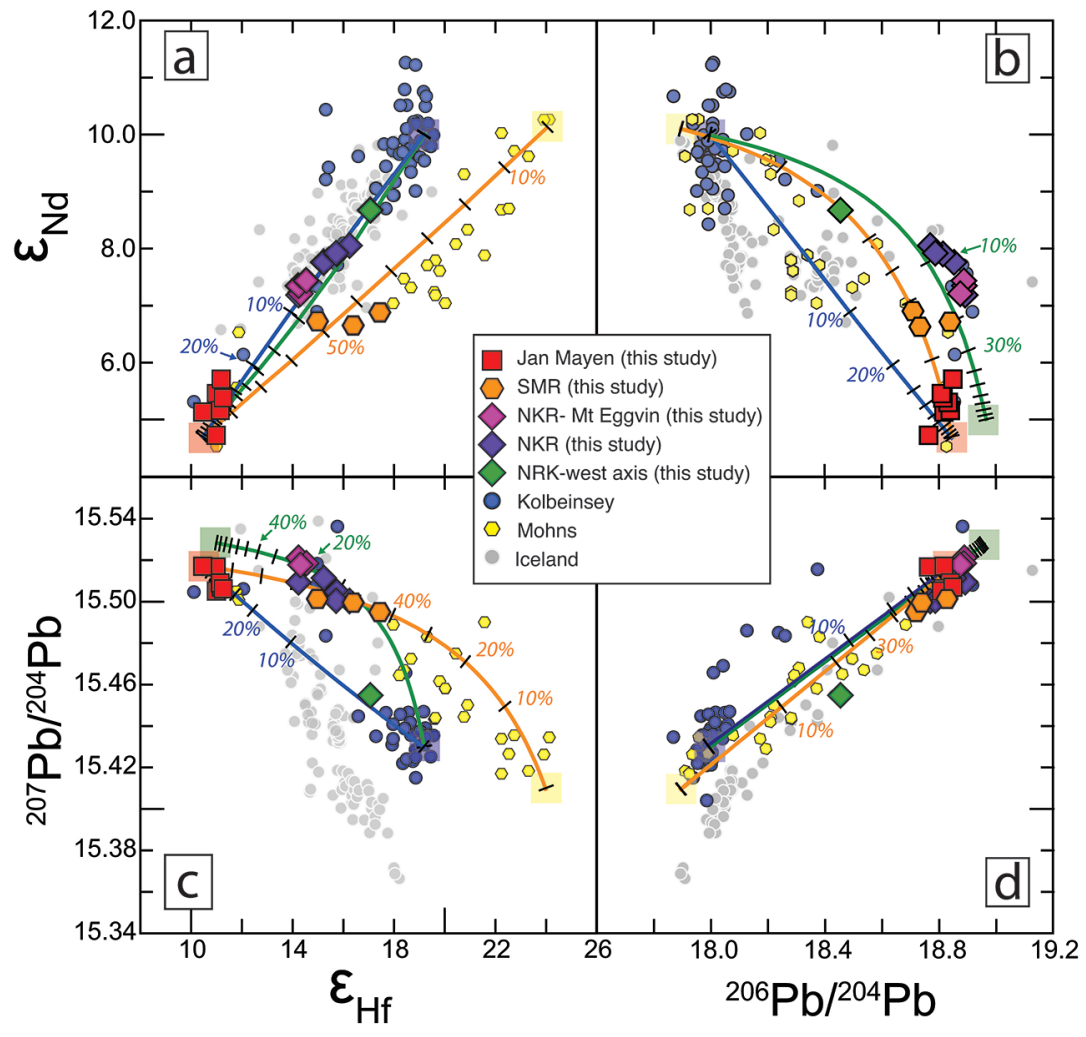

Figure 2 (a) $\varepsilon_{\mathrm{Nd}}$ vs. $\varepsilon_{\mathrm{Hf}}$ (b) $\varepsilon_{\mathrm{Nd}}$ vs. ${ }^{206} \mathrm{~Pb} /{ }^{204} \mathrm{~Pb}$, (c) ${ }^{207} \mathrm{~Pb} / 204 \mathrm{~Pb}$ vs. $\varepsilon_{H f}$, and (d) ${ }^{207} \mathrm{~Pb} / 204 \mathrm{~Pb}$ vs.

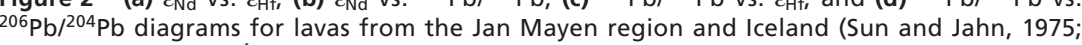
Zindler et al., 1979; Óskarsson et al., 1982; Hemond et al., 1993; Nowell et al., 1998; Salters and White, 1998; Schilling et al., 1999; Chauvel and Hémond, 2000; Kempton et al., 2000; Stracke et al., 2003; Blichert-Toft et al., 2005; Elkins et al., 2011; Sims et al., 2013; Elkins et al., 2014) (Tables 1, S-2). Curves show calculated binary mixing trajectories between hypothesised geochemical compositions for Jan Mayen-(red box), Mohns-(yellow), Kolbeinsey-(blue) and

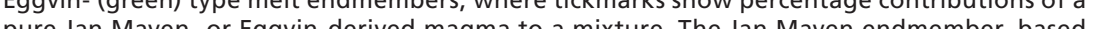
pure Jan Mayen- or Eggvin-derived magma to a mixture. The an Mayen endmember, based

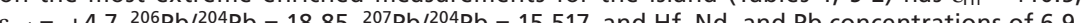
$\varepsilon^{\mathrm{Nd}}=+4.7,20 \mathrm{~Pb} / \mathrm{Pb}=18.85$, $2 \mathrm{~Pb} / \mathrm{Pb}=15.517$, and $\mathrm{HF}, \mathrm{Nd}$, and $\mathrm{Pb}$ concentrations of 6.9 , that that best explain available SMR samples as binary mixtures of an Mayen-Mohns Ridge lavas, has f $5.6,30$, and $0.7,1, \mathrm{pm}$, measure, and from the resped (2005; Elkins et al. 2014). The Kolbeinsey endmem suite of published MKR mo sute 2011) and NKR samp ${ }^{207} \mathrm{~Pb} / 204 \mathrm{~Pb}=15.43$, and $\mathrm{Hf}$, Nd, and $\mathrm{Pb}$ concentrations of 0.5 , 3 , and $0.3 \mathrm{ppm}$, respectively; 
mixtures of Jan Mayen and Kolbeinsey endmembers cannot fully explain NKR lava compositions. The Eggvin-type component was extrapolated to values that best explain NKR basalts as mixtures between Kolbeinsey and an unknown enriched component, with $\varepsilon_{\mathrm{Hf}}=+11, \varepsilon_{\mathrm{Nd}}=+5$ ${ }^{206} \mathrm{~Pb} / 204 \mathrm{~Pb}=18.96,{ }^{207} \mathrm{~Pb} / 204 \mathrm{~Pb}=15.528,{ }^{208} \mathrm{~Pb} /{ }^{204} \mathrm{~Pb}=38.72$, and $\mathrm{Hf}, \mathrm{Nd}$, and $\mathrm{Pb}$ concentrations of 3,22, and $11 \mathrm{ppm}$. Note that the high Pb content of the Eggvin-type endmember is necessary to generate a sufficiently hyperbolic mixing trajectory to account for NKR basalts.

Haase et al., 2003; Mertz et al., 2004; Blichert-Toft et al., 2005). Likewise, NKR $\alpha_{\mathrm{Sm}-\mathrm{Nd}}$ values (where $\alpha_{\mathrm{Sm}-\mathrm{Nd}}=(\mathrm{Sm} / \mathrm{Nd})_{\text {sample }} /(\mathrm{Sm} / \mathrm{Nd})_{\text {source, }}$ and $(\mathrm{Sm} / \mathrm{Nd})_{\text {source }}$ is calculated from ${ }^{143} \mathrm{Nd} /{ }^{144} \mathrm{Nd}_{\text {sample }}$ using a mantle model age of $1.8 \mathrm{Ga}$; DePaolo, 1988; Sims et al., 1995; Salters, 1996) are more typical of global MORB $(<1.0)$, unlike other Kolbeinsey Ridge basalts with $\alpha_{\mathrm{Sm}-\mathrm{Nd}}>1.0$ (Salters, 1996; Elkins et al., 2011), supporting a distinct mantle source beneath the NKR. While high $\left.{ }^{230} \mathrm{Th} /{ }^{238} \mathrm{U}\right)$ activity ratios have suggested melting of a depleted garnet peridotite source for the MKR, NKR lavas have low $\left({ }^{231} \mathrm{~Pa} /{ }^{235} \mathrm{U}\right)$ activity ratios, likely the product of rapid melting of garnet-bearing eclogite (Elkins et al., 2011, 2014). We note that the basalt from the eastern axial valley resembles other NKR lavas, including geochemical indicators of enrichment, while the western axial valley basalt more closely resembles MKR basalts and presumably does not sample the enriched mantle component beneath the Eggvin Bank (Figs. 2, 3, S-1, S-2).

While the above observations may suggest plume influence on NKR basalt production, the composition of the enriched endmember in the NKR/Eggvin mantle source differs notably from the Jan Mayen mantle component inferred from Jan Mayen Island- and SMR-derived lavas (Fig. 2). For example, the more enriched basalts collected from the Eggvin Bank exhibit lower $(\mathrm{Sm} / \mathrm{Yb})_{\mathrm{N}}$ ratios than the Jan Mayen endmember (Table S-2, Figs. 3, S-1), which cannot be explained by a lack of residual garnet in the source, since NKR magmas are known to be products of melting in the presence of garnet from ${ }^{230} \mathrm{Th} /{ }^{238} \mathrm{U}>1$ (Elkins et al., 2011, 2014). Observed NKR trace element patterns thus likely reflect the composition of a distinct mantle source located beneath the Eggvin Bank. Although no as pronounced as DUPAL-type signatures to the north, this Eggvin-type mantle source also exhibits slightly elevated ${ }^{207} \mathrm{~Pb} /{ }^{204} \mathrm{~Pb}$ and ${ }^{208} \mathrm{~Pb} /{ }^{204} \mathrm{~Pb}$ ratios for a given ${ }^{206} \mathrm{~Pb} / 204 \mathrm{~Pb}$ and higher $\varepsilon_{\mathrm{Hf}}$ for a given $\varepsilon_{\mathrm{Nd}}$ (Table 1, Figs. 2, S-2). Moreover, if generated by binary mixing, the isotopic compositions of Eggvin Bank basalts require a notably $\mathrm{Pb}$-rich Eggvin endmember magma (Fig. 2). In addition to the ${ }^{231} \mathrm{~Pa} /{ }^{235} \mathrm{U}$ evidence for eclogite (Elkins et al., 2014), partition coefficients for $\mathrm{Pb}$, $\mathrm{Si}, \mathrm{Al}$, and $\mathrm{Fe}$ in eclogite support an eclogite-rich source contributing magmas with the relatively high $\mathrm{Pb}$ and $\mathrm{SiO}_{2}$ and low $\mathrm{FeO}$ and $\mathrm{Al}_{2} \mathrm{O}_{3}$ observed in NKR MORB (Haase et al., 2003; Pertermann and Hirschmann, 2003) (Tables S-2, S-3, Figs. S-2, S-3, S-4). Such an eclogite-bearing source is supported by correlations between $\mathrm{Pb}$ and radiogenic isotopes, with higher $\mathrm{Pb}$ contents associated with the most enriched isotopic signatures for the NKR (Fig. S-4). We thus infer that the most likely mantle source for the Eggvin-type signature in NKR basalts is an eclogite-rich mantle containing ancient, high- $\varepsilon_{\mathrm{Hf}}$ garnet (Blichert-Toft et al., 2005). Existing models suggest that garnet-bearing veins or blobs of SCLM are present in the North Atlantic mantle, likely having originated under Greenland

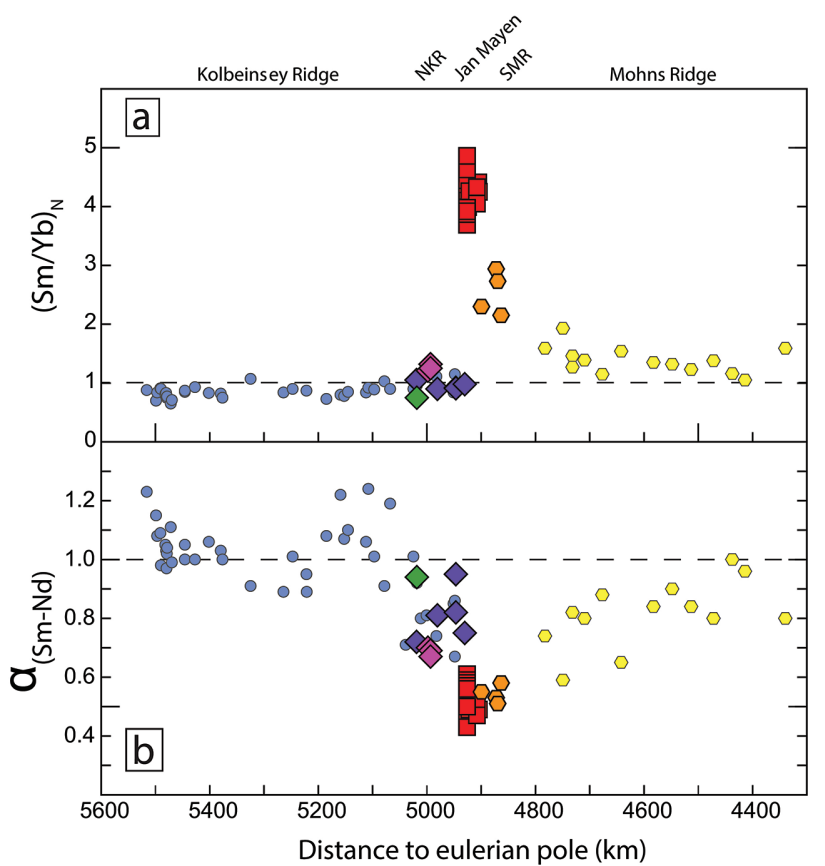

Figure 3 Geochemical indicators vs. along-axis distance for the NKR and SMR, with the position of Jan Mayen Island projected westward onto the NKR using a geographic contour that runs parallel to the Jan Mayen Fracture Zone. (a) $(\mathrm{Sm} / \mathrm{Yb})_{N}$, sensitive to the presence of garnet in, and the trace element makeup of, the source. The variation between Jan Mayen Island/SMR and the NKR likely reflects a heterogeneous mantle source. (b) $\alpha_{\mathrm{sm}-\mathrm{Nd} \text {; because } \mathrm{Sm}}$ is always more compatible than Nd during melting, values less than unity reflect the degree of melting of the model source, while values greater than unity (e.g., MKR basalts; Salters, 1996;
Elkins et al.,2011) require a different source composition and/or younger age than recorded Elkins et al., 2011) requir
by radiogenic isotopes.

prior to basin rifting by delamination (Blichert-Toft et al., 2005); a concentrated pocket of such material may plausibly have been trapped beneath the NKR by the relocation of the active ridge axis to the Kolbeinsey Ridge from the Aegir Ridge at $25 \mathrm{Ma}$ (Fig. 1). While the more fusible eclogite can generate thickened crust without elevated mantle temperatures, the other morphological evidence (large near-axis seamounts and paired axial valleys) and extreme nature of the crustal thickening would also support the influence of a plume on mantle temperature beneath the NKR.

The proximity of a small, discrete mantle plume beneath Jan Mayen Island could generate enhanced upwelling and elevated mantle temperatures, producing more melt regionally on both the SMR and NKR. The flow of plume-derived material would likely be directed northward across the fracture zone, influencing 
both mantle temperature and basalt composition along the SMR. While a highly fusible eclogite-rich source beneath Jan Mayen is a possibility that cannot be definitively ruled out, the diminishing northward Jan Mayen-type magma signature on the Mohns Ridge is more characteristic of a plume-like point source mixing with adjacent ridge-derived magmas. Any possible Jan Mayen hotspot track is likely confused by the off-axis hotspot location and a local tectonic history of axial relocation, possibly ongoing on the NKR, making the presence of a track unclear. The more fusable, eclogite-bearing, Eggvin-type mantle beneath the NKR could likewise be influenced by the elevated regional temperature anomaly caused by a Jan Mayen plume through the long-term generation of excess magma, although the NKR does not record direct mixing or addition of Jan Mayen-type mantle melts. While we believe this evidence likely favours a small, discrete mantle plume, either scenario results in crustal emplacement of large quantities of magma, producing highly thickened crust, voluminous sheet flows, and a nearly-subaerial (28 m depth), near-axis volcanic seamount.

Jan Mayen and environs demonstrate the dramatic extent to which magmatism generated by heterogeneous mantle, possibly with a plume source, can influence the structure and behaviour of ultraslow mid-ocean ridges. Here, multiple mantle heterogeneities within a relatively small geographic area have significantly modified the accretionary process of two ridge segments, generating enhanced magmatic activity, variations in spreading direction, adjusted axial locations, and, where mantle flow permits, the direct addition of heterogeneous, possibly plume-derived magma. We hence assert that the distinct morphology and tectonically-dominated accretionary style typical of ultraslow spreading ridges (Dick et al., 2003) is particularly sensitive to even modest increases in mantle temperature and magma supply, which cause the ridge to take on growth properties more typical of slow- or intermediate-spreading ridges. For comparison, the $17^{\circ} \mathrm{S}$ location on the East Pacific Rise is adjacent to a small hotspot but shows little geomorphological impact at fast spreading rates (Mahoney et al., 1994). This demonstrates that for ultraslow ridges, the control on accretionary mechanisms is principally magma supply, which is typically but, importantly, not solely controlled by spreading rate.

\section{Acknowledgements}

L.J.E. and K.W.W.S. acknowledge the Ocean Sciences Section of the National Science Foundation for supporting USA geochemical work and travel for this project. Geochemical analyses and field work were supported by the Norwegian Research Council in Norway to C.H. and R.P., and by the French Agence Nationale de la Recherche (ANR-10-BLAN-0603 M\&Ms - Mantle Melting Measurements, Models, Mechanisms) to J.B.T. I.A.Y. was supported by an A.v. Humboldt Fellowship. Jan Mayen Island samples from the Maaløe collection were supplied by D. DePaolo. Analyses at Boston University were performed by T. Ireland. We thank N. Augustin, M. Deutschmann, T. Laurila, K. Meisenhelder, E.
Rivers, M. Rothenbeck, F. van der Zwan, and I. Yeo for field assistance on the F.S Poseidon expedition in 2012; N. Augustin, I. Yeo, K. Meisenhelder, and R. Davis for assistance with bathymetric data; and E. Rivers, R. Davis, K. Meisenhelder, R. Chernow, Y. Ronen, S.H. Dundas, O. Tumyr and P. Telouk for assistance in the laboratory.

Editor: Graham Pearson

\section{Additional Information}

Supplementary Information accompanies this letter at www.geochemicalperspectivesletters.org/article1606

Reprints and permission information is available online at http://www. geochemicalperspectivesletters.org/copyright-and-permissions

Cite this letter as: Elkins, L.J., Hamelin, C., Blichert-Toft, J., Scott, S.R., Sims, K.W.W., Yeo, I.A., Devey, C.W., Pedersen, R.B. (2016) North Atlantic hotspot-ridge interaction near Jan Mayen Island. Geochem. Persp. Let. 2, 55-67.

\section{Author Contributions}

L.J.E. and C.H. conceived and led linked projects, made many of the measurements, and wrote the paper. J.B.T. and S.R.S. made many additional measurements. K.W.W.S. and C.W.D. provided conceptual input and insights and aided in data interpretation. I.A.Y., C.D., and R.P. aided in conceptual input regarding the field area, geomorphology, and sample collection. All authors contributed intellectually and substantively to the paper.

\section{References}

Blichert-Toft, I., Agranier, A., Andres, M., Kingsley, R., Schilling, J.G., Albarède, F. (2005) Geochemical segmentation of the Mid-Atlantic Ridge north of Iceland and ridgeF. (2005) Geochemical segmentation of the Mid-Atlantic Ridge north of Iceland and ridge-
hot spot interaction in the North Atlantic. Geochemistry Geophysics Geosystems 6, doi: hot spot interaction in

Chauvel, C., Hémond, C. (2000) Melting of a complete section of recycled oceanic crust: Trace element and Pb isotopic evidence from Iceland. Geochemistry Geophysics Geosystems 1, 1001.

Debaille, V., Trønnes, R.G., Brandon, A.D., Waight, T.E., Graham, D.W., Lee, C.-T.A. (2009) Primitive off-rift basalts from Iceland and Jan Mayen: Os-isotopic evidence for a mantle source containing enriched subcontinental lithosphere. Geochimica et Cosmochimica Acta 73 , 3423-3449.

DePAOLO, D. (1988) Neodymium isotope geochemistry: An introduction. 
DEVEY, C. (2012) RV Poseidon Cruise Report 436 [POS436]: North Kolbeinsey Ridge - geochemistry an volcanology, 06.07.2012 (Kiel) - 31.07.2012 (Akureyri). GEOMAR, Kiel, Germany, doi: 10.3289 CR_POS_436.

Dick, H.J.B., Lin, J., Schouten, H. (2003) An ultraslow-spreading class of ocean ridge. Nature $426,405-412$

Elkins, L.J., Sims, K.W.W., Prytulak, J., Mattielli, N., Elliott, T., Blichert-Toft, J., BluszTAJN, J., DunBar, N., DeveY, C. W., MerTZ, D.F., SCHILLING, J.G. (2011) Understanding
melt generation beneath the slow spreading Kolbeinsey Ridge from ${ }^{238} \mathrm{U}$, ${ }^{230} \mathrm{Th}$, and ${ }^{231} \mathrm{~Pa}$ melt generation beneath the slow spreading Kolbeinsey
excesses. Geochimica et Cosmochimica Acta 75, 6300-6329.

Elkins, L.J., Sims, K.W.W., Prytulak, J., Blichert-Toft, J., Elliott, T., Blusztajn, J., FretZDORFF, S., ReAGAN, M., HAASE, K., HumpHriS, S., SchillinG, J.G. (2014) Melt generation beneath Arctic Ridges: Implications from U decay series disequilibria in the Mohns, Knipovich, and Gakkel Ridges. Geochimica et Cosmochimica Acta 127, 140-170

GainA, C., Gernigon, L., BALL, P. (2009) Palaeocene-Recent plate boundaries in the NE Atlantic and the formation of the Jan Mayen microcontinent. Journal of the Geological Society of London $166,601-616$.

Gale, A., Dalton, C.A., Langmuir, C.H., Su, Y., Schilling, J.G. (2013) The mean composition of ocean ridge basalts. Geochemistry Geophysics Geosystems 14, 489-518

Gale, A., Langmuir, C.H., DaLton, C.A. (2014) The global systematics of ocean ridge basalts and their origin. Journal of Petrology 55, 1051-1082.

GÉLI, L., ReNARD, V., ROMmEVAUX, C. (2012) Ocean crust formation processes at very slow spreading centers: A model for the Mohns RIdge, near $72^{\circ} \mathrm{N}$, based on magnetic, gravity, and seismic data. Journal of Geophysical Research: Solid Earth 99, 2995-3013.

Haase, K.M., Devey, C.W., MertZ, D.F., Stoffers, P., Garbe-SchönberG, D. (1996) Geochemistry of lavas from Mohns ridge, Norwegian-Greenland Sea: Implications for melting conditions and magma sources near Jan Mayen. Contributions to Mineralogy and Petrology 123 223-237.

HaASE, K.M., DeveY, C.W., WiENEKE, M. (2003) Magmatic processes and mantle heterogeneity beneath the slow-spreading northern Kolbeinsey Ridge segment, North Atlantic. Contributions to Mineralogy and Petrology 144, 428-448.

Hanan, B.B., Blichert-Toft, J., Kingsley, R., Schilling, J.G. (2000) Depleted Iceland mantle plume geochemical signature: artifact of multicomponent mixing? Geochemistry Geophysics Geosystems 1, doi: 10.1029/1999GC000009.

Hemond, C., Arndt, N.T., Lichtenstein, U., Hofmann, A.W., Oskarsson, N., SteinTHORSSON, S. (1993) The Heterogeneous Iceland Plume - Nd-Sr-O Isotopes and Trace-Elemen Constraints. Journal of Geophysical Research-Solid Earth 98, 15833-15850.

IMSLAND, P. (1986) The volcanic eruption on Jan Mayen, January 1985: Interaction between a volcanic island and a fracture zone. Journal of Volcanology and Geothermal Research 28, 45-53.

JoHnson, G.L., HeEZen, B.C. (1967) Arctic Mid-Oceanic Ridge. Nature 215, 724-728.

Kandilarov, A., Mjelde, R., OKINO, K., Murai, Y. (2008) Crustal structure of the ultra-slow spreading Knipovich Ridge, North Atlantic, along a presumed amagmatic portion of oceani crustal formation. Marine Geophysical Researches 29, 109-134

Kandilarov, A., Mjelde, R., Pedersen, R.B., Hellevang, B., Papenberg, C., Petersen, C.J., PLANERT, L., FLUEH, E. (2012) The northern boundary of the Jan Mayen microcontinent, North Atlantic determined from ocean bottom seismic, multichannel seismic, and gravity data. Marine Geophysical Research 33, 55-76

Kempton, P.D., FitTon, J.G., SAunders, A.D., Nowell, G.M., TAYlor, R.N., Hardarson, B.S., PeArson, G. (2000) The Iceland plume in space and time: a Sr-Nd-Pb-Hf study of the North Atlantic rifted margin. Earth and Planetary Science Letters 177, 255-271.
KLINGeLHOFeR, F., GéLI, L., White, R.S. (2000) Geophysical and geochemical constraints on crustal accretion at the very-slow spreading Mohns Ridge. Geophysical Research Letters 27, 1547-1550.

Kodaira, S., Mjelde, R., Gunnarsson, K., Shiobara, H., Shimamura, H. (1997) Crustal structure of the Kolbeinsey Ridge, North Atlantic, obtained by use of ocean bottom seismographs. Journal of Geophysical Research-Solid Earth 102, 3131-3151.

Ljones, F., Kuwano, A., Mjelde, R., Breivik, A., Shimamura, H., Murai, Y., Nishimura, Y. (2004) Crustal transect from the North Atlantic Knipovich Ridge to the Svalbard margin west of hornsund. Tectonophysics 378, 17-41.

Maaløe, S., Sørensen, I. B., Hertogen, J. (1986) The trachybasaltic suite of Jan Mayen. Journal of Petrology 27, 439-466.

Mahoney, J.J., Sinton, J.M., Kurz, M.D., Macdougall, J.D., Spencer, K.J., Lugmair, G.W. (1994) Isotope and trace element characteristics of a super-fast spreading ridge: East Pacific Rise, 13-23 ${ }^{\circ}$. Earth and Planetary Science Letters 121, 173-193.

Mertz, D.F., Devey, C.W., Todt, W., Stoffers, P., Hofmann, A.W. (1991) Sr-Nd-Pb Isotope Evidence against Plume Asthenosphere Mixing North of Iceland. Earth and Planetary Science Letters 107, 243-255.

MerTZ, D.F., SHARP, W.D., HAASE, K.M. (2004) Volcanism on the Eggvin Bank (Central NorwegianGreenland Sea, latitude similar to 71 degrees N): age, source, and relationship to the Icelan and putative Jan Mayen plumes. Journal of Geodynamics 38, 57-83.

MOSAR, J., LEWIS, G., TORSVIK, T.H. (2002) North Atlantic sea-floor spreading rates: implications for the Tertiary development of inversion structures of the Norwegian-Greenland Sea. Journal of the Geological Society of London 159, 503-515.

Neumann, E.R., SChilling, J.G. (1984) Petrology of Basalts from the Mohns-Knipovich Ridge - the Norwegian-Greenland Sea. Contributions to Mineralogy and Petrology 85, 209-223.

Nowell, G.M., Kempton, P.D., Noble, S.R., Fitton, J.G., Saunders, A.D., Mahoney, J.J, TAYLOR, R.N. (1998) High precision Hf isotope measurements of MORB and OIB by therma Ionisation mass spectrometry; insights into the depleted mantle. Chemical Geology 149, 211-233.

Okino, K., Curewitz, D., Asada, M., Tamaki, K., Vogt, P., Crane, K. (2002) Preliminary analysis of the Knipovich Ridge segmentation: influence of focused magmatism and ridge
obliquity on an ultraslow spreading system. Earth and Planetary Science Letters 202, 275-288.

Óskarsson, N., SigValdason, G., Steinthorsson, S. (1982) A dynamic model of rift zone petrogenesis and the regional petrology of Iceland. Journal of Petrology 23, 28-74.

Pedersen, R.B., Thorseth, I.H., NyGÅrd, T.E., Lilley, M.D., Kelley, D.S. (2010) Hydrothermal activity at the Arctic mid-ocean ridges. In: Rona, P.A., Devey, C.W., Dyment, J., Murton, B.J. (Eds.) Diversity of Hydrothermal Systems on Slow Spreading Ocean Ridges. AGU, 67-89.

Pertermann, M., Hirschmann, M. (2003) Partial melting experiments on MORB-like pyroxenite between 2 and $3 \mathrm{GPa}$ : Constraints on the presence of pyroxenite in basalt source regions from solidus location and melting rate. Journal of Geophysical Research 108, doi: 10.1029/2000JB000118.

SALTERS, V.J.M. (1996) The generation of mid-ocean ridge basalts from the $\mathrm{Hf}$ and $\mathrm{Nd}$ isotope perspective. Earth and Planetary Science Letters 141, 109-123.

SALters, V.J.M., White, W.M. (1998) Hf isotope constraints on mantle evolution. Chemical Geology $145,447-460$.

SCHILLING, J.G. (1991) Fluxes and excess temperatures of mantle plumes inferred from their interaction with migrating mid-ocean ridges. Nature 352, 397-403

Schilling, J.G., Zajac, M., Evans, R., Johnston, T., White, W., Devine, J.D., Kingsley, R. (1983) Petrologic and Geochemical Variations Along the Mid-Atlantic Ridge from 29-Degrees$\mathrm{N}$ to 73 -Degrees-N. American Journal of Science 283, 510-586.

Schilling, J.G., Thompson, G., Kingsley, R., Humphris, S. (1985) Hotspot-migrating ridge interaction in the South Atlantic. Nature 313, 187-191. 
Schilling, J.G., Kingsley, R., Fontignie, D., Poreda, R., XUE, S. (1999) Dispersion of the Jan Mayen and Iceland mantle plumes in the Arctic: A He-Pb-Nd-Sr isotope tracer study of basalts from the Kolbeinsey, Mohns, and Knipovich Ridges. Journal of Geophysical Research-Solid Earth 104, 10543-10569

Sims, K.W.W., Depaolo, D.J., Murrell, M.T., Baldridge, W.S., Goldstein, S.J., Clague, D.A. (1995) Mechanisms of Magma Generation beneath Hawaii and Midocean Ridges - Uranium Thorium and Samarium/Neodymium Isotopic Evidence. Science 267, 508-512.

Sims, K.W.W., Maclennan, J., Blichert-Toft, J., Mervine, E. M., Blusztajn, J., GrÖnvold, K. (2013) Short length scale mantle heterogeneity beneath Iceland probed by glacial modulation of melting. Earth and Planetary Science Letters 379, 146-157.

SMITH, W.H.F., SANDWELL, D.T. (1997) Global sea floor topography from satellite altimetry and ship depth soundings. Science 277, 1956-1962.

Stracke, A., Zindler, A., Salters, V.J.M., McKenzie, D., Blichert-Toft, J., Albarède, F, Gronvold, K. (2003) Theistareykir revisited. Geochemistry Geophysics Geosystems 4, doi: 10.1029/2001gC000201.

Sun, S.S., JAHN, B. (1975) Lead and Strontium Isotopes in Postglacial Basalts from Iceland. Nature $255,527-530$

Thy, P., Lofgren, G.E., IMSLAND, P. (1991) Melting relations and the evolution of the Jan Mayen magma system. Journal of Petrology 32, 303-332.

Trønnes, R.G., Planke, S., Sundvoll, B., Imsland, P. (1999) Recent volcanic rocks from Jan Mayen: Low-degree melt fractions of enriched northeast Atlantic mantle. Journal of Geophysical Research-Solid Earth 104, 7153-7168.

ZINDLER, A., HART, S.R., FREY, F.A. (1979) Nd and Sr isotope ratios and rare earth element abundances in Reykjanes Peninsula basalts evidence for mantle heterogeneity beneath Iceland. Earth and Planetary Science Letters 45, 249-262 